\title{
Biomarkers and acute brain injuries: interest and limits
}

\author{
Ségolène Mrozek ${ }^{1}$ Julien Dumurgier ${ }^{2}$, Giuseppe Citerio ${ }^{3}$, Alexandre Mebazaa $^{4}$ and Thomas Geeraerts ${ }^{1 *}$
}

\begin{abstract}
For patients presenting with acute brain injury (such as traumatic brain injury, subarachnoid haemorrhage and stroke), the diagnosis and identification of intracerebral lesions and evaluation of the severity, prognosis and treatment efficacy can be challenging. The complexity and heterogeneity of lesions after brain injury are most probably responsible for this difficulty. Patients with apparently comparable brain lesions on imaging may have different neurological outcomes or responses to therapy. In recent years, plasmatic and cerebrospinal fluid biomarkers have emerged as possible tools to distinguish between the different pathophysiological processes. This review aims to summarise the plasmatic and cerebrospinal fluid biomarkers evaluated in subarachnoid haemorrhage, traumatic brain injury and stroke, and to clarify their related interests and limits for diagnosis and prognosis. For subarachnoid haemorrhage, particular interest has been focused on the biomarkers used to predict vasospasm and cerebral ischaemia. The efficacy of biomarkers in predicting the severity and outcome of traumatic brain injury has been stressed. The very early diagnostic performance of biomarkers and their ability to discriminate ischaemic from haemorrhagic stroke were studied.
\end{abstract}

\section{Introduction}

Despite significant advances in understanding the pathophysiology of brain injuries, there has been little change in terms of therapeutic or pharmacological treatment in recent years. The complexity and heterogeneity of lesions after brain injury are most probably responsible, at least in part, for the lack of positive results in clinical trials.

\footnotetext{
* Correspondence: geeraerts.t@chu-toulouse.fr

${ }^{1}$ Anesthesiology and Critical Care Department, Hopital Purpan, University Hospital of Toulouse, University Toulouse 3 Paul Sabatier, 1 place du Dr Baylac, 31059 Toulouse, France

Full list of author information is available at the end of the article
}

Furthermore, patients with apparently comparable brain lesions on imaging may have different neurological outcomes or responses to therapy. The use of biomarkers in the setting of brain injury may be of interest not only for diagnosis and identification of intracranial lesions but also for the evaluation of the severity, prognosis and treatment efficacy. In addition, patient stratification, based on biomarkers, may be useful in clinical trials for selecting a homogeneous population and decreasing inclusion disparity.

Brain biomarker detection in the cerebrospinal fluid (CSF) and in the blood has been described. Due to the separation of the brain from the blood by the bloodbrain barrier $(\mathrm{BBB})$, proteins produced within the brain are present only in small quantities in the blood if the $\mathrm{BBB}$ is intact. The BBB status (open or closed) therefore has a strong influence on the amount of those types of proteins in the blood and must be taken into consideration for the interpretation of brain injury blood biomarkers.

The aim of this review is to summarise plasmatic and CSF biomarkers evaluated in subarachnoid haemorrhage (SAH), traumatic brain injury (TBI) and stroke, and to clarify their interest and limits for diagnosis and prognosis. Of note, the present review will not describe the neurological prognostic factors after cardiopulmonary resuscitation in patients with cardiac arrest. Serum levels of proteins neuron-specific enolase (NSE) and S100 $\beta$ are considered promising candidates for neurological predictors, and a review on the clinical usefulness of these markers has been published previously [1].

\section{Subarachnoid haemorrhage \\ Initial severity and prognosis of subarachnoid haemorrhage}

Several biomarkers have been studied in terms of the short-term or long-term neurological prognostic factors and correlation with initial severity of patients after aneurysmal SAH [2-13]. Table 1 summarises different biomarkers and their correlation with initial neurological patient severity and prognosis. 
Table 1 Main biomarkers of subarachnoid haemorrhage, and dosage correlated with initial severity, neurological prognosis and mortality

\begin{tabular}{|c|c|c|c|c|c|c|c|c|c|c|}
\hline \multirow[b]{2}{*}{ Biomarker } & \multicolumn{2}{|c|}{ Dosage } & \multicolumn{4}{|c|}{ Initial severity } & \multicolumn{3}{|l|}{ GOS } & \multirow[b]{2}{*}{ Mortality } \\
\hline & $\overline{\mathrm{CSF}}$ & Plasma & $\overline{\mathrm{GCS}}$ & WFNS & $\mathrm{HH}$ & Fisher & 3 months & 6 months & 12 months & \\
\hline$\overline{\mathrm{ET}}-1$ & + & + & & & $+(\mathrm{CSF})$ & & & & & $\begin{array}{l}+ \\
\text { (plasma) }\end{array}$ \\
\hline TNF-a & + & + & & & - (SF) & & $-($ CSF $)$ & & & \\
\hline IL-6 & + & & & & - & & & + & & \\
\hline $\mathbb{I L}-1 \beta$ & + & & & & - & & - & & & \\
\hline ICAM-1, VCAM-1 & + & + & & $\begin{array}{l}\text { - (CSF } \\
\text { plasma) }\end{array}$ & $\begin{array}{l}\text { - (CSF, } \\
\text { plasma) }\end{array}$ & & & & $\begin{array}{l}\text { - (CSF, } \\
\text { plasma) }\end{array}$ & \\
\hline Light-chain NF & + & & & & & & & & + & \\
\hline Heavy-chain NF & + & & + & + & & & + & & & \\
\hline ApoE & + & & + & & & - & + & & & \\
\hline$S 100 \beta$ & + & + & $-(\mathrm{CSF})$ & + (plasma) & & + (plasma) & $-($ CSF) & $\stackrel{+}{+}$ & & \\
\hline ANP & & + & & & + (plasma) & + (plasma) & & & & \\
\hline BNP & & + & & & & + & & & & + \\
\hline cTnl & & + & + & & + & + & + & & & + \\
\hline $\begin{array}{l}\text { VWF, MMP-9, } \\
\text { VEGF }\end{array}$ & & + & & & & + & & & & \\
\hline CRP & + & + & $\begin{array}{l}+(\mathrm{CSF} \\
\text { plasma) }\end{array}$ & & $\begin{array}{l}+(\mathrm{CSF} \\
\text { plasma) }\end{array}$ & $\begin{array}{l}+(\mathrm{CSF} \\
\text { plasma) }\end{array}$ & $\begin{array}{l}+(\mathrm{CSF} \\
\text { plasma })\end{array}$ & & & \\
\hline
\end{tabular}

+, correlation described; -, lack of correlation; plasma/CSF, dosing site. ANP, atrial natriuretic peptide; ApoE, apolipoprotein E; BNP, brain natriuretic peptide; cTnl, cardiac troponin I; CRP, C-reactive protein; CSF, cerebrospinal fluid; ET-1, endothelin-1; Fisher, Fisher classification; GCS, Glasgow Coma Scale; GOS, Glasgow Outcome Scale; HH, Hunt and Hunter classification; ICAM-1, intercellular adhesion molecule-1; IL, interleukin; MMP-9, matrix metalloproteinase-9; NF, neurofilament; S100 $\beta$, S100 $\beta$ protein; TNF, tumour necrosis factor; VCAM-1, vascular cell adhesion molecule-1; VEGF, vascular endothelial growth factor; vWF, von Willebrand factor; WFNS, World Federation of Neurosurgeons classification.

\section{Vasospasm and cerebral ischaemia}

Cerebral vasospasm and its related cerebral ischaemia remain the primary cause of mortality and neurological deficit after $\mathrm{SAH}$ and the most powerful predictors of long-term outcome $[14,15]$. Physiological and morphological changes observed during cerebral vasospasm occur in two phases: a contraction of the arterial wall in the first 72 hours after onset of $\mathrm{SAH}$, followed by smooth muscle cell proliferation in the intima of the main cerebral arteries. Indeed, sustained arterial contraction causes an increase in the shear stress of endothelial cells, from day 3 to day 14 after SAH, with an increase in endothelial permeability, expression of intercellular adhesion molecules with intimal infiltration of leukocytes, platelet adhesion to the internal elastic lamina, migration of smooth muscle cells and myointimal proliferation [16,17]. Plasma and CSF biomarkers have been studied in the context of SAH, in relation to vasospasm and other factors such as systemic inflammation, microcirculatory disorders or microembolic release $[18,19]$. A recent review classified CSF biomarkers for cerebral vasospasm according to reports in the literature as markers with auspicious value, candidate markers with insufficient evidence and noncandidate markers with no reference to cerebral vasospasm [20].

\section{Cytokines}

An inflammatory response similar to that observed during coronary spasm appears to affect the cerebral circulation of patients with SAH. Proinflammatory cytokines - that is, IL-1 $\beta$, IL- 6 and tumour necrosis factor alpha - have been detected in the CSF of patients with SAH, with a peak between day 5 and day 9 followed by a gradual decrease [2]. Peak concentrations of cytokines have been found to be increased up to 10,000-fold, in the range detected in bacterial meningitis [21]. The concentrations of IL-1 $\beta$ and IL-6 are lower in the plasma than in the CSF, suggesting a cerebral origin of these mediators with a release mechanism.

The triggers for this marked inflammatory response in the subarachnoid space of patients with SAH are still unknown. One hypothesis is a complement activation method via osmotically induced disruption of erythrocytes [22,23]. A study of 35 patients with SAH revealed parallel changes in the velocities of the middle cerebral artery using transcranial Doppler and concentrations of IL-1 $\beta$, IL-6 and tumour necrosis factor alpha in the CSF [2]. Another study of $64 \mathrm{SAH}$ patients confirmed the increase in CSF IL-6 (peak at day 4 to day 5) before the onset of clinical signs of vasospasm (peak at day 6 to day 7 ), with a threshold of $2,000 \mathrm{pg} / \mathrm{ml}$ at day 4 for the 
prediction of the development of symptomatic vasospasm (sensitivity $=89 \%$ and specificity $=78 \%$ ) [24]. Another recent study in $38 \mathrm{SAH}$ patients reported higher concentrations of IL- 6 in the CSF, brain extracellular fluid and plasma of symptomatic patients than in those of asymptomatic patients with vasospasm [25].

\section{Natriuretic peptides}

Atrial natriuretic peptide and brain natriuretic peptide (BNP) are produced in the heart in response to neural and humoral stimuli and fluid overload [26]. BNP is therefore not brain specific, but is also produced in brain tissue, especially in the hypothalamus. Two possible mechanisms for increased BNP production in the hypothalamus have been advanced: release secondary to humoral or paracrine signals, and a response to hypoxia due to vasospasm. Some evidence suggests that cerebral ischaemia after $\mathrm{SAH}$ is not only caused by large vessel spasm [27]. Many hypotheses to explain this phenomenon have been proposed, including systemic infarction, microcirculatory spasm, and the release of microemboli $[18,19]$.

BNP may be a marker of a general process of microcirculatory dysfunction characterised by systemic inflammation and local thrombosis, as described in sepsis or haemorrhagic shock [28]. In addition, a recent study links BNP release to proinflammatory cytokines [29]. Berendes and colleagues [30] and Tomida and colleagues [31] reported an association between plasma BNP concentration and the development of delayed ischaemic neurological deficit (DIND). Sviri and colleagues [32] studied 38 patients with $\mathrm{SAH}$ and observed an increase in plasma BNP between day 1 and day $3(69.6 \pm 92.4 \mathrm{pg} / \mathrm{ml})$ compared with control patients $(5.8 \pm 1.9 \mathrm{pg} / \mathrm{ml})$. Patients not presenting with DIND have displayed a progressive decrease from day 3 in plasma BNP concentration. On the contrary, patients with DIND have displayed a gradual increase in plasma BNP concentration between day 3 and day 12 post-SAH [32]. A recent study of 119 patients revealed a significant association between a BNP level $>276 \mathrm{pg} / \mathrm{ml}$ in the plasma and the onset of cerebral ischaemia [27]. Of note, BNP is biologically active and may increase the risk of cerebral ischaemia by its direct effects on the kidneys and systemic vessels, including natriuresis, vasodilatation and hypovolaemia.

\section{von Willebrand factor, vascular endothelial growth factor and matrix metalloproteinase-9}

During cerebral vasospasm, sustained arterial contraction is at the origin of increases in the shear stress of endothelial cells and is associated with modifications of endothelial permeability, expression of adhesion molecules and myointimal proliferation [16,17]. Vascular endothelial growth factor (VEGF) can initiate these changes because its concentration is increased in the intima after endothelial cell damage [33,34]. Matrix metalloproteinase-9 (MMP-9) alone can stimulate the activity of VEGF by increasing the availability of VEGF in the media of vessels [35]. Moreover, MMP-9 expression is increased in smooth muscle cells after alterations of endothelial cells, contributing to the initiation of myointimal proliferation [36].

von Willebrand factor is considered a plasma marker of endothelial cell injury. McGirt and colleagues have demonstrated an increase in plasma concentrations of VEGF, MMP-9 and von Willebrand factor before the diagnosis of vasospasm by both transcranial Doppler and cerebral angiography in 38 patients with SAH [13]. Peak concentrations were observed for von Willebrand factor, MMP-9 and VEGF at day 5, day 3 and day 2, respectively. Elevated plasma von Willebrand factor levels $>5,500 \mathrm{ng} / \mathrm{ml}$, MMP-9 levels $>700 \mathrm{ng} / \mathrm{ml}$ and VEGF levels $>0.12 \mathrm{ng} / \mathrm{ml}$ each independently increased the odds of vasospasm (17-fold, 25 -fold and 21-fold, respectively). However, the plasma concentrations of these markers were not different between clinically symptomatic and asymptomatic patients with vasospasm. Recently, Chou and colleagues reported the lack of a correlation between CSF or plasmatic MMP-9 and vasospasm in 55 patients with SAH [5].

\section{Endothelin-1}

Endothelin-1 has major vasoconstrictive effects in human arteries, including cerebral vessels [37]. Furthermore, endothelin-1 has been found in neurons, glial cells, the choroid plexus and macrophages. The concentration of endothelin-1 in the CSF of SAH patients was significantly higher $(2.5 \pm 0.7 \mathrm{pg} / \mathrm{ml})$ on the first day after onset of SAH than in the CSF of controls (normal values $<0.85 \mathrm{pg} / \mathrm{ml}$ ) [38]. Endothelin-1 concentrations in CSF increase until the sixth day and then gradually decrease in patients without vasospasm. In addition, a significant increase in CSF endothelin-1 has been observed between day 4 and day 7 in symptomatic patients with vasospasm $[38,39]$. One study found an endothelin-1 increase in the CSF before detection of angiographic vasospasm [38]. Moreover, a significant correlation has been found between the concentration of endothelin-1 in the CSF and the extension of angiographic vasospasm [40]. In plasma, no significant difference in endothelin-1 concentration has been demonstrated between patients with SAH and controls [41].

Endothelin receptor antagonists have emerged as a promising therapeutic option. A recent Cochrane database review concluded that endothelin receptor antagonists appear to reduce DIND and angiographic vasospasm, but their benefit to clinical outcome remains unproven. Moreover, their associated adverse events were not negligible (for example, hypotension and pneumonia) [42]. 


\section{Intercellular adhesion molecule-1 and vascular cell adhesion molecule-1}

There is a large amount of evidence that inflammatory reactions may be involved in the pathogenesis of delayed ischaemic lesions. Several molecules could initiate the steps of the inflammatory cascade. These include intercellular adhesion molecule-1, an immunoglobulin-like molecule that is exposed to endothelial cells and induced by exposure to inflammatory cytokines, and vascular cell adhesion molecule-1 $[43,44]$. Animal studies have demonstrated an upregulation of intercellular adhesion molecule- 1 on endothelial and medial layers of cerebral arteries after SAH. Treatment with monoclonal antibodies against intercellular adhesion molecule-1 can reduce or even inhibit cerebral vasospasm in animals [45]. An increase in the blood and CSF concentrations of intercellular adhesion molecule-1 and vascular cell adhesion molecule- 1 in patients with SAH compared with a control group within the first 7 days has been described [7]. There appears to be a correlation between cerebral blood flow velocities measured using transcranial Doppler and a secondary increase of intercellular adhesion molecule-1 and vascular cell adhesion molecule-1 in plasma and CSF [46].

\section{Neurofilaments}

Neurofilaments are components of the axonal cytoskeleton and include heavy-chain neurofilaments (NF-H; 190 to $210 \mathrm{kDa})$, medium-chain neurofilaments $(160 \mathrm{kDa})$, light-chain neurofilaments $(68 \mathrm{kDa})$ and $\alpha$-internexin (66 kDa) [47]. In physiological conditions, neurofilaments are restricted to the intracellular compartment of the neuronal cells. Alteration of the axonal membrane integrity can result in the release of neurofilament proteins in the extracellular space and their spread into the CSF. The subunits of neurofilaments are therefore potentially useful for revealing axonal injury.

Plasma NF-H concentrations in healthy individuals average $0.11 \mathrm{ng} / \mathrm{ml}$, and CSF NF-H concentrations average $0.94 \mathrm{ng} / \mathrm{ml}$ [48]. Petzold and colleagues reported a positive correlation between CSF concentrations of NF-H and prognosis (Glasgow Outcome Scale at 3 months) in SAH patients [49]. Lewis and colleagues confirmed that high concentrations of NF-H in plasma and CSF were associated with a poor outcome at 6 months and that patients with vasospasm had increased levels of NF-H in CSF and plasma $(16.7 \pm 19.9 \mathrm{ng} / \mathrm{ml}$ and $0.44 \pm 0.68 \mathrm{ng} / \mathrm{ml}) \mathrm{com}-$ pared with patients without vasospasm $(0.29 \pm 0.44 \mathrm{ng} / \mathrm{ml}$ and $8.3 \pm 15.3 \mathrm{ng} / \mathrm{ml}$ ) [9]. NF-H may thus be a useful marker of axonal injury in SAH.

More recently, Zanier and colleagues [41] reported higher concentrations of light-chain neurofilaments in CSF obtained by external ventricular shunt in patients with early cerebral ischaemia defined by hypodense lesion on computed tomography (CT) within 72 hours of ruptured aneurysm (related to intracranial haemorrhage or complications of aneurysm treatment). However, there were no significant differences in external ventricular shunt light-chain neurofilaments concentrations between patients who developed clinical vasospasm and those with delayed cerebral ischaemia [41].

\section{a2-spectrin breakdown products}

$\alpha 2$-spectrin is a cytoskeletal protein. The products of its degradation by calpain and caspase- 3 are potential markers of the severity of lesions in SAH. $\alpha 2$-spectrin is transformed into degradation products of $150 \mathrm{kDa}$ (SBDP150) and $145 \mathrm{kDa}$ (SBDP145) by calpain and is cleaved into a degradation product of $120 \mathrm{kDa}$ (SBDP120) by caspase-3 [50]. Calpain and caspase-3 are major effectors of cell death (respectively, necrotic and apoptotic). In a study of 20 patients with a high Fisher grade of SAH, Lewis and colleagues reported an increase in SBDP concentration in the CSF [51]. SBDP150, SBDP145 and SBDP120 CSF concentrations were higher in patients with clinical vasospasm compared with patients who did not develop vasospasm. Moreover, symptomatic vasospasm was associated with an increase in the concentrations of SBDPs (SBDP145 and SBDP150) in the CSF 12 hours prior. The treatment of vasospasm induced a decrease in SBDPs to baseline levels in patients without ischaemia, but SBDP concentrations remained high in patients with cerebral ischaemia.

\section{S100 $\beta$ protein}

S100 $\beta$ protein belongs to a multigenic family of low molecular weight (9 to $13 \mathrm{kDa}$ ) calcium-binding S100 proteins. $\mathrm{S} 100 \beta$ protein is mainly expressed in glial cells, particularly astrocytes [52]. S100 $\beta$ protein is involved in intracellular signal transduction via the inhibition of protein phosphorylation, regulation of enzyme activities and affecting calcium homeostasis [53]. In addition, S100 $\beta$ protein participates in the regulation of cell morphology by interacting with elements of the cytoplasmatic cytoskeleton. S100 $\beta$ protein is actively secreted into the CSF from astrocytes and is believed to have extracellular functions. The protein can be detected in both CSF (normal value 1 to $2 \mu \mathrm{g} / \mathrm{l}$ ) and blood serum (normal value $<0.15 \mu \mathrm{g} / \mathrm{l}$ ), resulting from the elimination process after intracellular and extracellular actions. S100 $\beta$ protein's biological half-life is 2 hours; the protein can be detected in both CSF and blood serum. Kay and colleagues report an increase (compared with a control population) of its concentration in CSF after SAH in patients with neurologic symptoms [10]. A recent study of 55 patients with SAH shows that plasma and CSF concentrations of $\mathrm{S} 100 \beta$ can detect cerebral ischaemia and intracranial hypertension after $\mathrm{SAH}$, a secondary increase in plasma concentration being predictive of vasospasm [54]. 


\section{Other biomarkers}

Recently, Siman and colleagues [55] studied combinations of neurodegeneration biomarkers for predicting vasospasm, infarction and outcome rather than the use of a single biomarker. They reported an increase for six CSF biomarkers from 3-fold to 10-fold between days 1 and 5 after $\mathrm{SAH}$ onset for patients with moderate to severe angiographic vasospasm (14-3-3 $\beta$ protein, $14-3-3 \zeta$ protein, ubiquitin C-terminal hydrolase-L-1 (UCH-L1), NSE and two SBDPs cleaved by calpain). These biomarkers were correlated significantly with occurrence of cerebral vasospasm, brain infarction and poor outcome. They reported the 14-3-3 $\beta$ protein, NSE and fragment N-terminal of SBDPs as early predictors of vasospasm [55].

In clinical practice, none of these biomarkers have been clearly validated for the early detection of cerebral vasospasm, the main cause of mortality and neurological deficit after SAH. Larger and prospective studies are required to validate their use for detection of vasospasm, but also to validate therapeutic options guided by biomarker levels aiming at improving neurological outcome.

\section{Traumatic brain injury}

TBI severity can be assessed using the Glasgow Coma Score (GCS) and brain imaging. Minor TBI (GCS 13 to 15 ) and moderate TBI (GCS 9 to 12) represent $90 \%$ of TBI cases, but these types of TBI may induce long-term sequelae. Because of the limits of GCS and imaging, the use of biomarkers to improve diagnosis and classification of TBI could be of interest.

\section{Initial severity, prognosis and mortality}

Many biomarkers have been studied in TBI to evaluate the association of initial severity with the GCS and neuroradiological findings at patient admission, neurologic outcome predictions with Glasgow Outcome Scale (GOS) at 3 months and 6 months, and mortality prediction. Several biomarkers have been found to correlate with these associated items: S100 $\beta$ protein [56,57], NSE [58,59], UCH-L1 [60-62], glial fibrillary acidic protein (GFAP) [57,58], myelin basic protein [63,64] and tau protein [65] in plasma, and S100 $\beta$ protein [56], UCH-L1, SBDPs $[66,67]$ and tau protein $[68]$ in CSF.

\section{Classification of traumatic brain injury}

A recent review summarised CSF and blood biomarkers of mild TBI to predict long-term neurological sequelae and to assess patients with head trauma by classifying them according to axonal, neuronal or astroglial injuries [69].

\section{S100 $\beta$ protein}

S100 $\beta$ protein can be released from astroglial cells in many ways: by activation of adenosine and glutamate receptors [70], by stimulation of astroglial 5HT1A receptors [71] and by adrenocorticotropic hormone and corticotrophin-like intermediate-lobe peptide [72]. Moreover, S100 $\beta$ protein is secreted from proliferating astrocytes.

In TBI patients, the acute increase in plasma S100 $\beta$ protein level is most probably related to massive adenosine and glutamate release in heavily damaged and perfused brain areas [73]. A portion of S100 $\beta$ protein is able to diffuse into the bloodstream. The determination of plasma S100 $\beta$ protein after TBI may be able to differentiate groups of patients with minor or severe injuries. In 226 patients with minor TBI (GCS 13 to 15), the plasma levels of $S 100 \beta$ were significantly higher in patients with intracranial injury, with a threshold value of $0.10 \mu \mathrm{g} / \mathrm{l}$ for detecting lesions on $\mathrm{CT}$ scan (area under receiver operating characteristic curve $=0.73(95 \% \mathrm{CI}=0.62$ to 0.84$)$ and sensitivity $=95 \%)$ [74]. For 2,128 patients with minor TBI, the plasma threshold was $0.12 \mu \mathrm{g} / \mathrm{l}$, with a sensitivity of $99 \%$ and a specificity around $20 \%$ for the detection of intracranial lesions on CT scan. The negative predictive value was $99.7 \%(95 \% \mathrm{CI}=98.1$ to $100 \%)$ [75]. A S100 $\beta$ protein level below $0.12 \mu \mathrm{g} / \mathrm{l}$ at patient admission could therefore be used to exclude post-traumatic intracranial lesions on CT scan. However, these data require confirmation in a larger study. S100 $\beta$ protein, initially considered to be located only in the central nervous system, is expressed in other tissues such as adipocytes or chondrocytes. High plasma protein S100 $\beta$ has been observed after multiple traumas in patients without brain damage, leading to questioning of its usefulness for predicting neurological outcome in those patients [76].

Goyal and colleagues [56] studied S100 $\beta$ protein temporal profiles in the CSF and plasma of adults with severe TBI. Their temporal serum profiles were associated with acute mortality, perhaps because of extracerebral sources in the serum as represented by high Injury Severity Scores, but the CSF S100 $\beta$ protein profiles were associated with outcomes and mortality [56]. In clinical practice, the S100 $\beta$ protein level can be obtained in 1 hour and its cost is approximately $€ 15$.

\section{Neuron-specific enolase}

NSE is one of the five isoenzymes of glycolytic enolase in central and peripheral neurons. NSE is localised in neuron cytoplasm and is most probably involved in the increase of chloride concentration at the beginning of neural activity [77]. This marker has been used to evaluate neuronal functional alterations. NSE is passively released rapidly in the plasma after TBI by cell destruction. The NSE plasma concentration at patient admission for TBI has been found to be twofold higher than normal reference values [58]. Despite these promising data, several studies have produced disappointing 
results. Because of the slow elimination (biological halflife of 48 hours) of NSE from the plasma, quantification of the amount of brain injury and distinction between primary and secondary insult remains difficult using plasma NSE [78]. Furthermore, NSE can be released into the plasma from red blood cell haemolysis, resulting in possible confounding factors [79].

\section{Ubiquitin C-terminal hydrolase-L-1}

$\mathrm{UCH}-\mathrm{L} 1$ is highly and specifically expressed in neurons. $\mathrm{UCH}-\mathrm{L} 1$ represents approximately 1 to $5 \%$ of the total soluble proteins within the brain [80]. This protein is involved in the addition and deletion of ubiquitin-dependent protein (via the ATP-dependent proteasome pathway), playing an important role in the removal of excessive, oxidised or abnormal proteins during normal and neuropathological conditions [81]. One study reports higher concentrations of UCH-L1 in the CSF of patients with severe TBI $(44.2 \mathrm{ng} / \mathrm{ml})$ compared with a control group $(2.7 \mathrm{ng} / \mathrm{ml})$ [60]. UCH-L1 is released within 6 hours after trauma and peaks in the first 24 hours in the CSF. This study reported an area under the curve (AUC) of 0.88 ( $95 \% \mathrm{CI}=0.68$ to 1.00 ) using UCH-L1 CSF levels within the first 6 hours versus control patients.

UCH-L1 appears to be able to distinguish TBI and uninjured control patients at 6 hours when the mental status can be confounded by drugs, alcohol or other pathology. Recently, Papa and colleagues [82] compared early UCH-L1 plasma levels (within 4 hours of injury) of patients with mild and moderate TBI with uninjured and injured control patients in a prospective cohort study. They reported a significant difference between UCH-L1 levels in CT-negative patients versus CT-positive patients $(0.62 \mathrm{ng} / \mathrm{ml}$ vs. $1.61 \mathrm{ng} / \mathrm{ml}$, respectively) with an AUC of 0.73 ( $95 \% \mathrm{CI}=0.62$ to 0.84 ). Moreover, UCH-L1 levels allow one to distinguish mild and moderate TBI from uninjured control patients with an AUC of 0.87 ( $95 \% \mathrm{CI}=0.82$ to 0.92$)$ and to distinguish TBI with GCS 15 from controls with an AUC of $0.87(95 \% \mathrm{CI}=0.81$ to 0.93) [82].

\section{Glial fibrillary acidic protein}

GFAP is a protein involved in astrocyte cytoskeletons by forming networks with filaments that provide support and strength to cells. Glial cells specifically express GFAP, which is involved in several neurological processes such as BBB integrity. An increase in the plasma concentrations of GFAP in patients with severe TBI $(0.10 \pm 0.18 \mu \mathrm{g} / \mathrm{l}$ on admission, $0.012 \pm 0.026 \mu \mathrm{g} / \mathrm{l} 24$ hours after injury and $0.017 \pm 0.052 \mu \mathrm{g} / \mathrm{l} 48$ hours after injury) has been reported compared with healthy volunteers $(0.004 \mu \mathrm{g} / \mathrm{l})$ [83].

Moreover, critically injured trauma patients without TBI had significantly lower levels of plasmatic GFAP compared with patients with TBI documented on head
CT scan [84]. In addition, the plasma concentration of GFAP is not affected by multiple traumas without brain injury [85]. GFAP has recently been reported as highly vulnerable to proteolytic modifications in vitro and in vivo. Breakdown products of GFAP are therefore likely to be present in biofluids. GFAP breakdown product levels are able to differentiate TBI patients from uninjured controls with an AUC of 0.90 (95\% CI $=0.86$ to 0.94) and differentiate TBI patients with a GCS of 15 from normal controls with an AUC of 0.88 (95\% CI = 0.82 to 0.93 ) [86]. More recently, the prospective Transforming Research and Clinical Knowledge in TBI study evaluated the diagnosis accuracy of elevated levels of GFAP breakdown products in TBI patients. This study confirms the good correlation between GFAP breakdown product levels and CT scan findings in TBI patients [87].

\section{a2-spectrin breakdown products}

Pineda and colleagues reported an increase in SBDP concentration in the CSF after severe TBI [66]. More recently, Mondello and colleagues [67] studied 40 severe TBI patients using SBDP measurement in the CSF from ventriculostomy catheters every 6 hours for a maximum of 7 days following TBI, comparing them with control patients. Compared with control patients, both SBDP145 $(14.42 \pm 0.91 \mathrm{ng} / \mathrm{ml}$ vs. $0.52 \pm 0.22 \mathrm{ng} / \mathrm{ml})$ and SBDP120 $(6.05 \pm 0.28 \mathrm{ng} / \mathrm{ml}$ vs. $1.21 \pm 0.48 \mathrm{ng} / \mathrm{ml})$ CSF concentrations were increased in severe TBI. The degradation of products appears to be different, with an earlier peak for SBDP145 (29.56 $\mathrm{ng} / \mathrm{ml}$ at 6 hours) compared with a late peak for SBDP120 (11.96 ng/ml at 138 hours). These observations suggest that cell death via necrosis or apoptosis is activated with a different time course after severe TBI. In addition, patients who died after TBI exhibited higher concentrations of SBDP145 and SBDP120 than survivors within 7 days post-trauma [67].

In clinical practice, only $S 100 \beta$ protein may be used to screen patients with minor TBI (GCS 13 to 15) and exclude CT-scan lesions when the plasma level is below $0.12 \mu \mathrm{g} / \mathrm{l}$ at admission. UCH-L1 may have the same utility but prospective studies with larger samples are required. GFAP has the advantage of not being influenced by peripheral injuries, contrary to $S 100 \beta$ protein and NSE, and is therefore probably more specific for brain injury [88]. The use of biomarkers for classification of TBI is certainly of major interest, but large clinical studies validating strategies based on biomarkers use in TBI are still lacking, particularly in severe TBI patients.

\section{Stroke}

The use of biomarkers to diagnose stroke very early and the precise extent of brain damage may be useful in the application of specific therapeutic strategies. The difficulty with this approach relates to the heterogeneity of 
the brain cell population, different tolerances to ischaemia and distribution in the central nervous system, complexity of the ischaemic cascade and integrity of the BBB. Biomarkers may also reflect the different steps of cerebral ischaemia, such as inflammation, glial activation and neuronal injury.

\section{S100 $\beta$ protein}

Several studies have described a significant increase in plasma levels of $S 100 \beta$ protein within the first 3 days after cerebral infarction [89,90]. In stroke, high levels of adenosine occur in the core of the infarct, not perfused with blood. S100 $\beta$ protein accumulated in this region cannot be released into the bloodstream and thus does not contribute to any observed increase in plasma levels. The pattern of reactive astrogliosis observed in animals and human studies explains the plasma $S 100 \beta$ protein temporal profiles in stroke patients, with plasma S100 $\beta$ protein peaking later than in TBI patients. A recent review described the serum S100 $\beta$ temporal profile after stroke onset. There is a gradual concentration increase starting 8 to 10 hours after onset of symptoms, followed by a peak at 72 hours and then a drop at 96 hours [91]. Lower plasma concentrations of S100 $\beta$ have been reported in only one study, in patients with transient ischaemic attack (TIA) or normal brain CT on admission in comparison with individuals with neurological deficits or abnormal brain imaging displaying cortical infarcts [73]. A correlation has been observed between plasma levels of $S 100 \beta$ protein and the size of cerebral infarction $[92,93]$. An association has been described between S100 $\beta$ protein plasma levels and the National Institutes of Health Stroke Score $[89,94]$. However, the delayed kinetics and low specificity preclude this association for diagnostic use in acute stroke situations. The increase in plasma $S 100 \beta$ is not specific for cerebral infarction and can be observed with other neurological conditions such as TBI and extracranial malignancies, possibly leading to biased interpretations of results. The clinical performance of $S 100 \beta$ protein therefore does not appear to be robust enough to differentiate ischaemic stroke, haemorrhagic stroke and stroke mimics.

Despite these factors, S100 $\beta$ concentrations could be an additional tool for the identification of patients at high risk of specific early neurological complications in clinical practice. Indeed, a plasmatic S100 $\beta$ level $>1.03 \mu \mathrm{g} / \mathrm{l}$ at 24 hours after the onset of stroke predicts malignant infarction in patients with proximal middle cerebral artery occlusion, with a sensitivity of $94 \%$ and a specificity of $83 \%$ [95]. Another study has reported higher S100 $\beta$ prethrombolysis concentrations in patients who developed haemorrhagic transformation after thrombolysis treatment compared with patients who did not $(0.14$ vs. $0.11 \mu \mathrm{g} / \mathrm{l})$ [96]. A recent study examined
458 patients with ischaemic stroke who were not treated with thrombolytic drugs. At admission, patients with clinical deterioration caused by haemorrhagic transformation had higher concentrations of $S 100 \beta$ and tightjunction proteins, which are markers of $\mathrm{BBB}$ breakdown. An analysis of these proteins levels could be used to screen for and predict the risk of haemorrhagic transformation [97].

\section{Asymmetric dimethylarginine}

Methylarginines are synthesised by post-translational methylation of 1-arginine and are released as free dimethylarginines after proteolysis. Asymmetric dimethylarginine (ADMA) and symmetric dimethylarginine are detectable in blood, urine and CSF. Whereas symmetric dimethylarginine is inactive, ADMA is a potential inhibitor of nitric oxide synthase, which is involved in endothelial dysfunction [98]. An increase in the ADMA plasma concentration is thus assumed to be a surrogate marker for the risk of ischaemic stroke.

Yoo and Lee reported a significant difference between ADMA plasma concentrations in healthy control patients $(0.93 \pm 0.32 \mu \mathrm{mol} / \mathrm{l})$, ischaemic stroke patients $(1.46 \pm 0.77 \mu \mathrm{mol} / \mathrm{l})$ and patients with initial recurrence of ischaemic stroke $(2.28 \pm 1.63 \mu \mathrm{mol} / \mathrm{l})$ [99]. Another study that included 880 women revealed that an increase of $0.15 \mu \mathrm{mol} / 1$ ADMA in plasma leads to a $30 \%$ increased risk of ischaemic stroke and myocardial infarction [100]. In addition, the Framingham Offspring Study evaluated plasma ADMA concentrations from 2,013 individuals for whom simultaneous neuroimaging studies were available. The ADMA concentration was independently associated with an increased prevalence of magnetic resonance imaging abnormalities in the absence of clinical symptoms, which is a well-known risk factor for pre-emptive stroke [101].

\section{Matrix metalloproteinase-9}

Matrix metalloproteinases are a family of zinc-dependent and calcium-dependent endopeptidases responsible for turnover and degradation of extracellular matrix proteins. The expression of MMP-9 in brain tissue under normal conditions is very low, but increases in MMP-9 expression have been demonstrated in ischaemic brain tissue [102]. The upregulation of MMP-9 occurs in brain tissue in response to injury and is believed to play a central role in the pathophysiology of ischaemic stroke by degradation of extracellular matrix proteins. After the onset of cerebral ischaemia, the uncontrolled expression and activity of MMP-9 mediate proteolysis and lead to BBB leakage and cell death.

Increases of MMP-9 plasma concentrations have been demonstrated in both ischaemic $(149.6 \pm 99 \mathrm{ng} / \mathrm{ml})$ and haemorrhagic stroke patients upon presentation to the 
emergency department compared with healthy individuals $(<97 \mathrm{ng} / \mathrm{ml})$, suggesting a relatively short time period (within hours) from release to detection in the plasma [103,104]. Plasma concentrations of MMP-9 are also related to cerebral infarction size, neurological outcomes and haemorrhagic transformation, especially after fibrinolysis [104-106]. At patient admission to the hospital, plasma concentrations of MMP-9 are predictive of cerebral infarct volume on magnetic resonance imaging and are correlated with stroke lesion growth, even after thrombolysis administration [107].

\section{$N$-methyl-d-aspartic acid receptor antibodies and peptides}

Receptors for $N$-methyl-D-aspartic acid bind the glutamate neurotransmitter and are expressed mainly by neuronal cells. The receptors contain four subunits (two NR1 and two NR2 subunits), and fragmentation of NR2 into NR2A and NR2B peptides is thought to occur during cerebral ischaemia or neurotoxicity $[108,109]$. The generation of $\mathrm{N}$-methyl-D-aspartic acid receptor antibodies (NR2Abs) is mediated by the immune response following ischaemic events. The NR2Abs and NR2 peptides can be assayed in blood and CSF.

Several studies have examined the potential usefulness of NR2Abs and NR2 peptides as markers of ischaemic stroke. Dambinova and colleagues reported an increase in NR2Ab plasma concentrations during ischaemic stroke $(5.01 \pm 1.23 \mu \mathrm{g} / \mathrm{l})$ and TIA $(4.02 \pm 2.04 \mu \mathrm{g} / \mathrm{l})$ in 105 patients compared with 255 control subjects $(1.49 \pm$ $0.22 \mu \mathrm{g} / \mathrm{l}$ ) [110]. NR2Abs are not able to discriminate stroke from TIA. Moreover, the NR2Ab increase is not observed after haemorrhagic stroke, suggesting that a negative NR2Ab result could be used to rule out haemorrhagic stroke. A threshold $\geq 2 \mu \mathrm{g} / \mathrm{l}$ has a sensitivity of $97 \%$ and a specificity of $98 \%$ in the diagnosis of ischaemic stroke or TIA within 3 hours after symptom onset. An increase of antibodies can be observed in hypertensive patients and in patients with a history of ischaemic stroke or atherosclerosis [110]. Thus, it is unclear whether the increase in antibody level reflects an acute episode of cerebral ischaemia or is a potential predictor of cerebrovascular events. A prospective multicentre study of 557 patients undergoing coronary surgery reported that 24 of 25 patients with a preoperative concentration NR2Ab $\geq 2 \mu \mathrm{g} / \mathrm{l}$ revealed neurologic complication within 48 hours after surgery [111].

\section{Glial fibrillary acidic protein}

Clinical studies have demonstrated an increase in GFAP plasma levels after ischaemic stroke compared with control subjects, with a peak between day 2 and day 4 after onset of symptoms [112]. A prospective study involving 135 patients admitted 6 hours after onset of stroke symptoms reported detection of serum GFAP in $81 \%$ of patients with haemorrhagic stroke but in only 5\% of those with ischaemic stroke [113]. Furthermore, plasma levels of GFAP were significantly higher in haemorrhagic stroke patients (mean value $111.6 \mathrm{ng} / \mathrm{l}$ ) than in ischaemic stroke patients (mean value $0.4 \mathrm{ng} / \mathrm{l}$ ). With a threshold value of $2.9 \mathrm{ng} / \mathrm{l}$, the sensitivity was $79 \%$ and the specificity was $98 \%$ for differentiating ischaemic stroke from haemorrhagic stroke. In a study by the same team, the optimal timing to differentiate cerebral ischaemia from haemorrhage with GFAP was 2 to 6 hours after symptom onset [114]. A multicentre study focusing on S100 $\beta$ protein, NSE, GFAP and activated protein $\mathrm{C}$-protein $\mathrm{C}$ inhibitor complex demonstrated the ability of GFAP to differentiate haemorrhagic stroke from ischaemic stroke, which has not been observed for other proteins [115]. Moreover, the combination of GFAP with activated protein $\mathrm{C}$-protein $\mathrm{C}$ inhibitor complex and the National Institutes of Health Stroke Score led to a diagnostic sensitivity and negative predictive value of $100 \%$, allowing exclusion of haemorrhagic stroke, which is potentially useful for early initiating fibrinolysis.

\section{Neuropeptide proenkephalin A and protachykinin}

Stroke has been characterised by biomarkers of infarct size and damage to the BBB. Recent studies have reported stable precursor fragments of the neuropeptides encephalin (proenkephalin A (PENK-A)) and substance $\mathrm{P}$ (protachykinin A) as potent markers of BBB integrity [116]. Both neuropeptides are active as neurotransmitters and are involved in nociception and immune stimulation. Doehner and colleagues [117] recently evaluated PENK-A and protachykinin A in 189 patients presenting with symptoms of acute cerebrovascular disease. Plasma concentrations of PENK-A were significantly increased in acute stroke patients (123.8 pmol/l) compared with patients with TIA (114.5 pmol/l) or nonischaemic events (102.8 pmol/l). The elevation of PENK-A was correlated with stroke severity (National Institutes of Health Stroke Score) and with CT infarct size. Moreover, increased PENK-A concentrations predicted 3-month outcomes for mortality, stroke recurrence and myocardial infarction. Protachykinin A concentrations did not demonstrate any discriminative power [117].

\section{Other biomarkers and biomarker combinations}

Several other biomarkers, mostly nonspecific, were studied either alone or in combination in the context of stroke. Combinations of several biomarkers have been developed to increase the sensitivity and specificity of the diagnosis [118-121].

In clinical practice, the main interest for stroke biomarkers is probably in the ability to discriminate ischaemic strokes from haemorrhagic strokes or TIA, allowing 


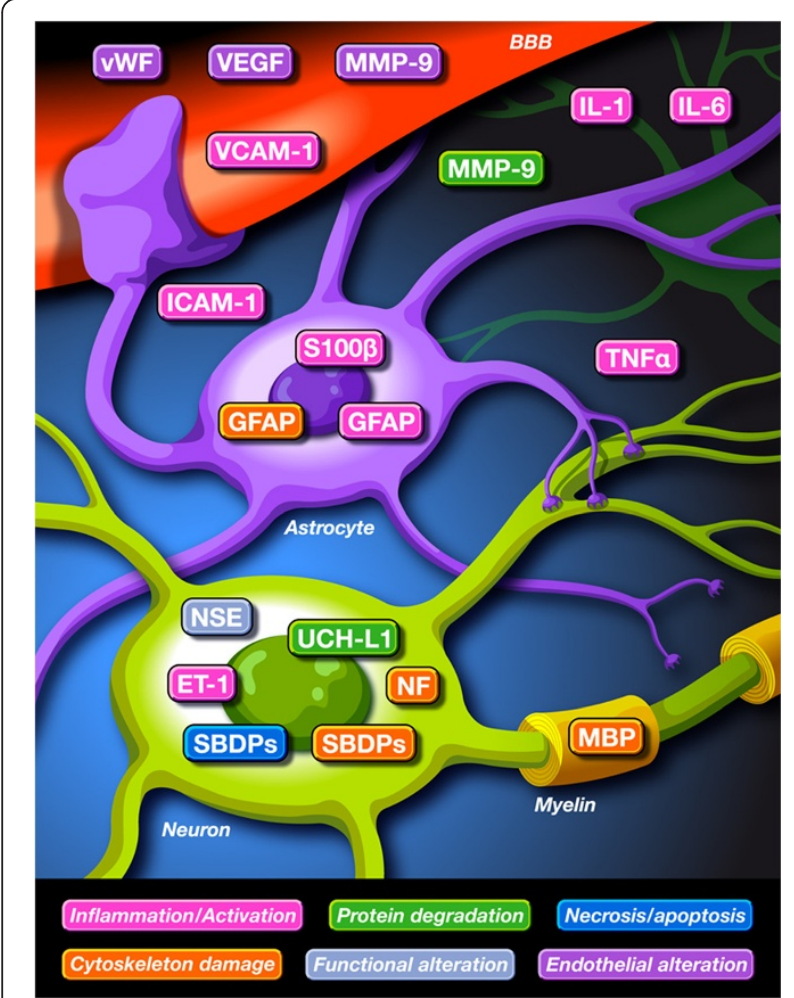

Figure 1 Main biomarkers used in subarachnoid haemorrhage, traumatic brain injury and stroke. Biomarkers can be classified according to their role in brain injuries: inflammation and activation; protein degradation; necrosis and apoptosis; cytoskeleton damage; functional alteration; and endothelial alteration. BBB, blood-brain barrier; ET-1, endothelin-1; GFAP, glial fibrillary acidic protein; ICAM-1, intercellular adhesion molecule-1; IL, interleukin; MBP, myelin basic protein; MMP-9, matrix metalloproteinase-9; NF, neurofilament; NSE, neuron-specific enolase; S100ß, S100 $\beta$ protein; SBDP, a2-spectrin breakdown product; TNF, tumour necrosis factor; UCH-L1, ubiquitin C-terminal hydrolase-L-1; VCAM-1, vascular cell adhesion molecule-1; VEGF, vascular endothelial growth factor; vWF, von Willebrand factor.

an early initiation of fibrinolysis. When taking into consideration the specificity for ischaemic event detection and the kinetics for biomarker increase, plasma PENK-A seems to be one of the most interesting biomarkers for acute ischaemic stroke detection.

Figure 1 summarises the main biomarkers examined in SAH, TBI and stroke. They are classified according to their significance in brain injury dynamics.

\section{Conclusion}

The use of biomarkers in the treatment of brain injuries and brain diseases is of considerable interest for improving diagnosis and prognostication. These surrogate markers must nevertheless be used with caution. Stricto sensu, their performance at predicting an event can be applied only to populations in which they have been validated. The overuse of biomarkers for brain injuries could induce both expensive and counterproductive strategies. However, it appears reasonable to limit their use for clinical research.

Research on biomarkers of brain injury should remain a strong priority, as biomarkers could be a key factor in personalised medicine. New developments such as omics tools should be used in stroke treatment and therapy, similar to how they have been used recently in cardiovascular disease [122]. In parallel with the discovery of new biomarkers of brain injury, the economic performance of these biomarkers needs to be evaluated in both large cohorts of patients and in selected and targeted populations with complicated clinical situations and high uncertainty.

\section{Abbreviations}

ADMA: Asymmetric dimethylarginine; AUC: Area under the curve; BBB: Blood-brain barrier; BNP: Brain natriuretic peptide; Cl: Confidence interval; CSF: Cerebrospinal fluid; CT: Computed tomography; DIND: Delayed ischaemic neurological deficit; GCS: Glasgow coma score; GFAP: Glial fibrillary acidic protein; IL: Interleukin; MMP-9: Matrix metalloproteinase-9; NF-H: Heavy-chain neurofilaments; NR2Ab: N-methyl-d-aspartic acid receptor antibody; NSE: Neuron-specific enolase; PENK-A: Proenkephalin A; SAH: Subarachnoid haemorrhage; SBDP: a2-spectrin breakdown product; TBI: Traumatic brain injury; TIA: Transient ischaemic attack; UCH-L1: Ubiquitin C-terminal hydrolase-L-1; VEGF: Vascular endothelial growth factor.

\section{Competing interests}

The authors declare that they have no competing interests.

\section{Author details}

${ }^{1}$ Anesthesiology and Critical Care Department, Hopital Purpan, University Hospital of Toulouse, University Toulouse 3 Paul Sabatier, 1 place du Dr Baylac, 31059 Toulouse, France. ${ }^{2}$ INSERM U942, University Paris Diderot, Sorbonne Paris Cite, CMRR Paris Nord-IDF, GH Saint Louis - Lariboisière Fernand Widal, F-75010 Paris, France. ${ }^{3}$ Neuroanaesthesia and Neurointensive Care Unit, Anestesia e Rianimazione, San Gerardo Hospital, via Pergolesi 33, 20900 Monza, Milan, Italy. ${ }^{4}$ Department of Anesthesia and Intensive Care, INSERM U942, Paris Diderot University, Lariboisière Hospital, 2 rue Ambroise Paré, 75010 Paris, France.

\section{Published: 24 Apr 2014}

\section{References}

1. Shinozaki K, Oda S, Sadahiro T, Nakamura M, Hirayama Y, Abe R, Tateishi Y, Hattori N, Shimada T, Hirasawa H: S-100B and neuron-specific enolase as predictors of neurological outcome in patients after cardiac arrest and return of spontaneous circulation: a systematic review. Crit Care 2009, 13:R121.

2. Fassbender K, Hodapp B, Rossol S, Bertsch T, Schmeck J, Schutt S, Fritzinger M, Horn P, Vajkoczy P, Kreisel S, Brunner J, Schmiedek P, Hennerici M: Inflammatory cytokines in subarachnoid haemorrhage: association with abnormal blood flow velocities in basal cerebral arteries. J Neurol Neurosurg Psychiatry 2001, 70:534-537.

3. Weiss N, Sanchez-Pena P, Roche S, Beaudeux JL, Colonne C, Coriat P, Puybasset $L$ : Prognosis value of plasma S100B protein levels after subarachnoid aneurysmal hemorrhage. Anesthesiology 2006, 104:658-666.

4. Fountas KN, Tasiou A, Kapsalaki EZ, Paterakis KN, Grigorian AA, Lee GP, Robinson JS Jr: Serum and cerebrospinal fluid C-reactive protein levels as predictors of vasospasm in aneurysmal subarachnoid hemorrhage, Clinical article. Neurosurg Focus 2009, 26:E22.

5. Chou SH, Feske SK, Simmons SL, Konigsberg RG, Orzell SC, Marckmann A, Bourget G, Bauer DJ, De Jager PL, Du R, Arai K, Lo EH, Ning MM: Elevated peripheral neutrophils and matrix metalloproteinase 9 as biomarkers of functional outcome following subarachnoid hemorrhage. Trans/ Stroke Res 2011, 2:600-607. 
6. Witkowska AM, Borawska MH, Socha K, Kochanowicz J, Mariak Z, Konopka M: TNF-alpha and sICAM-1 in intracranial aneurismal rupture. Arch Immunol Ther Exp (Warsz) 2009, 57:137-140.

7. Kaynar MY, Tanriverdi T, Kafadar AM, Kacira T, Uzun H, Aydin S, Gumustas K, Dirican A, Kuday C: Detection of soluble intercellular adhesion molecule-1 and vascular cell adhesion molecule- 1 in both cerebrospinal fluid and serum of patients after aneurysmal subarachnoid hemorrhage. J Neurosurg 2004, 101:1030-1036.

8. Kessler IM, Pacheco YG, Lozzi SP, de Araujo AS Jr, Onishi FJ, de Mello PA: Endothelin-1 levels in plasma and cerebrospinal fluid of patients with cerebral vasospasm after aneurysmal subarachnoid hemorrhage. Surg Neurol 2005, 64(Suppl 1):S1:2-S1:5. discussion S1:5.

9. Lewis SB, Wolper RA, Miralia L, Yang C, Shaw G: Detection of phosphorylated NF-H in the cerebrospinal fluid and blood of aneurysmal subarachnoid hemorrhage patients. J Cereb Blood Flow Metab 2008, 28:1261-1271

10. Kay A, Petzold A, Kerr M, Keir G, Thompson E, Nicoll J: Decreased cerebrospinal fluid apolipoprotein $E$ after subarachnoid hemorrhage: correlation with injury severity and clinical outcome. Stroke 2003, 34:637-642.

11. Yarlagadda S, Rajendran P, Miss JC, Banki NM, Kopelnik A, Wu AH, Ko N, Gelb AW, Lawton MT, Smith WS, Young WL, Zaroff JG: Cardiovascular predictors of in-patient mortality after subarachnoid hemorrhage. Neurocrit Care 2006, 5:102-107.

12. Nakagawa I, Kurokawa S, Nakase H: Hyponatremia is predictable in patients with aneurysmal subarachnoid hemorrhage - clinical significance of serum atrial natriuretic peptide. Acta Neurochir (Wien) 2010, 152:2147-2152.

13. McGirt MJ, Lynch JR, Blessing R, Warner DS, Friedman AH, Laskowitz DT: Serum von Willebrand factor, matrix metalloproteinase-9, and vascular endothelial growth factor levels predict the onset of cerebral vasospasm after aneurysmal subarachnoid hemorrhage. Neurosurgery 2002, 51:1128-1134. discussion 1134-1135.

14. Fergusen S, Macdonald RL: Predictors of cerebral infarction in patients with aneurysmal subarachnoid hemorrhage. Neurosurgery 2007, 60:658-667. discussion 667

15. Rosengart AJ, Schultheiss KE, Tolentino J, Macdonald RL: Prognostic factors for outcome in patients with aneurysmal subarachnoid hemorrhage. Stroke 2007, 38:2315-2321.

16. Liszczak TM, Varsos VG, Black PM, Kistler JP, Zervas NT: Cerebral arterial constriction after experimental subarachnoid hemorrhage is associated with blood components within the arterial wall. J Neurosurg 1983, $58: 18-26$.

17. Takemae T, Branson PJ, Alksne JF: Intimal proliferation of cerebral arteries after subarachnoid blood injection in pigs. J Neurosurg 1984, 61:494-500

18. Macdonald RL, Pluta RM, Zhang JH: Cerebral vasospasm after subarachnoid hemorrhage: the emerging revolution. Nat Clin Pract Neurol 2007, 3:256-263.

19. Dhar $\mathrm{R}$, Diringer $M N$ : The burden of the systemic inflammatory response predicts vasospasm and outcome after subarachnoid hemorrhage. Neurocrit Care 2008, 8:404-412.

20. Lad SP, Hegen H, Gupta G, Deisenhammer F, Steinberg GK: Proteomic biomarker discovery in cerebrospinal fluid for cerebral vasospasm following subarachnoid hemorrhage. J Stroke Cerebrovasc Dis 2012, 21:30-41.

21. Fassbender K, Ries S, Schminke U, Schneider S, Hennerici M: Inflammatory cytokines in CSF in bacterial meningitis: association with altered blood flow velocities in basal cerebral arteries. J Neurol Neurosurg Psychiatry 1996, 61:57-61.

22. Peterson JW, Kwun BD, Teramura A, Hackett JD, Morgan JA, Nishizawa S, Bun T, Zervas NT: Immunological reaction against the aging human subarachnoid erythrocyte, A model for the onset of cerebral vasospasm after subarachnoid hemorrhage. J Neurosurg 1989, 71(5 Pt 1):718-726.

23. Kasuya $\mathrm{H}$, Shimizu T: Activated complement components $\mathrm{C} 3 \mathrm{a}$ and $\mathrm{C} 4 \mathrm{a}$ in cerebrospinal fluid and plasma following subarachnoid hemorrhage. J Neurosurg 1989, 71(5 Pt 1):741-746.

24. Schoch B, Regel JP, Wichert M, Gasser T, Volbracht L, Stolke D: Analysis of intrathecal interleukin- 6 as a potential predictive factor for vasospasm in subarachnoid hemorrhage. Neurosurgery 2007, 60:828-836. discussion 828-836.

25. Sarrafzadeh A, Schlenk F, Gericke C, Vajkoczy P: Relevance of cerebral interleukin- 6 after aneurysmal subarachnoid hemorrhage. Neurocrit Care 2010, 13:339-346.
26. Levin ER, Gardner DG, Samson WK: Natriuretic peptides. N Engl J Med 1998, 339:321-328.

27. Taub PR, Fields JD, Wu AH, Miss JC, Lawton MT, Smith WS, Young WL, Zaroff JG, Ko NU: Elevated BNP is associated with vasospasmindependent cerebral infarction following aneurysmal subarachnoid hemorrhage. Neurocrit Care 2011, 15:13-18

28. Zakynthinos E, Kiropoulos T, Gourgoulianis K, Filippatos G: Diagnostic and prognostic impact of brain natriuretic peptide in cardiac and noncardiac diseases. Heart Lung 2008, 37:275-285.

29. de Bold AJ: Cardiac natriuretic peptides gene expression and secretion in inflammation. J Investig Med 2009, 57:29-32.

30. Berendes E, Walter M, Cullen P, Prien T, Van Aken H, Horsthemke J, Schulte $M$, von Wild K, Scherer R: Secretion of brain natriuretic peptide in patients with aneurysmal subarachnoid haemorrhage. Lancet 1997, 349:245-249.

31. Tomida M, Muraki M, Uemura K, Yamasaki K: Plasma concentrations of brain natriuretic peptide in patients with subarachnoid hemorrhage. Stroke 1998, 29:1584-1587.

32. Sviri GE, Shik V, Raz B, Soustiel JF: Role of brain natriuretic peptide in cerebral vasospasm. Acta Neurochir Wien) 2003, 145:851-860. discussion 860.

33. Wysocki SJ, Zheng MH, Smith A, Norman PE: Vascular endothelial growth factor (VEGF) expression during arterial repair in the pig. Eur J Vasc Endovasc Surg 1998, 15:225-230

34. Martin J: Learning from vascular remodelling. Clin Exp Allergy 2000, 30(Suppl 1):33-36.

35. Bergers G, Brekken R, McMahon G, Vu TH, Itoh T, Tamaki K, Tanzawa K, Thorpe P, Itohara S, Werb Z, Hanahan D: Matrix metalloproteinase-9 triggers the angiogenic switch during carcinogenesis. Nat Cell Biol 2000, 2:737-744.

36. Zempo N, Koyama N, Kenagy RD, Lea HJ, Clowes AW: Regulation of vascular smooth muscle cell migration and proliferation in vitro and in injured rat arteries by a synthetic matrix metalloproteinase inhibitor. Arterioscler Thromb Vasc Biol 1996, 16:28-33.

37. Adner M, Jansen I, Edvinsson L: Endothelin-A receptors mediate contraction in human cerebral, meningeal and temporal arteries. J Auton Nerv Syst 1994, 49(Suppl):S117-S121.

38. Suzuki K, Meguro K, Sakurai T, Saitoh Y, Takeuchi S, Nose T: Endothelin-1 concentration increases in the cerebrospinal fluid in cerebral vasospasm caused by subarachnoid hemorrhage. Surg Neurol 2000, 53:131-135.

39. Kastner S, Oertel MF, Scharbrodt W, Krause M, Boker DK, Deinsberger W: Endothelin-1 in plasma, cisternal CSF and microdialysate following aneurysmal SAH. Acta Neurochir (Wien) 2005, 147:1271-1279. discussion 1279 .

40. Mascia L, Fedorko L, Stewart DJ, Mohamed F, TerBrugge K, Ranieri VM, Wallace MC: Temporal relationship between endothelin-1 concentrations and cerebral vasospasm in patients with aneurysmal subarachnoid hemorrhage. Stroke 2001, 32:1185-1190.

41. Zanier ER, Refai D, Zipfel GJ, Zoerle T, Longhi L, Esparza TJ, Spinner ML, Bateman RJ, Brody DL, Stocchetti N: Neurofilament light chain levels in ventricular cerebrospinal fluid after acute aneurysmal subarachnoid haemorrhage. J Neurol Neurosurg Psychiatry 2011, 82:157-159.

42. Guo J, Shi Z, Yang K, Tian JH, Jiang L: Endothelin receptor antagonists for subarachnoid hemorrhage. Cochrane Database Syst Rev 2012, 9:CD008354.

43. Sills AK Jr, Clatterbuck RE, Thompson RC, Cohen PL, Tamargo RJ: Endothelial cell expression of intercellular adhesion molecule 1 in experimental posthemorrhagic vasospasm. Neurosurgery 1997 41:453-460. discussion 460-461

44. Nissen JJ, Mantle D, Gregson B, Mendelow AD: Serum concentration of adhesion molecules in patients with delayed ischaemic neurological deficit after aneurysmal subarachnoid haemorrhage: the immunoglobulin and selectin superfamilies. J Neurol Neurosurg Psychiatry 2001, 71:329-333.

45. Oshiro EM, Hoffman PA, Dietsch GN, Watts MC, Pardoll DM, Tamargo RJ: Inhibition of experimental vasospasm with anti-intercellular adhesion molecule-1 monoclonal antibody in rats. Stroke 1997, 28:2031-2037. discussion 2037-2038.

46. Rothoerl RD, Schebesch KM, Kubitza M, Woertgen C, Brawanski A, Pina AL: ICAM-1 and VCAM-1 expression following aneurysmal subarachnoid hemorrhage and their possible role in the pathophysiology of subsequent ischemic deficits. Cerebrovasc Dis 2006, 22:143-149.

47. Van Geel WJ, Rosengren LE, Verbeek MM: An enzyme immunoassay to quantify neurofilament light chain in cerebrospinal fluid. J Immunol Methods 2005, 296:179-185. 
48. Petzold A, Shaw G: Comparison of two ELISA methods for measuring levels of the phosphorylated neurofilament heavy chain. $\mathrm{J}$ Immunol Methods 2007, 319:34-40.

49. Petzold A, Keir G, Kay A, Kerr M, Thompson EJ: Axonal damage and outcome in subarachnoid haemorrhage. I Neurol Neurosurg Psychiatry 2006, 77:753-759.

50. Pike BR, Flint J, Dave JR, Lu XC, Wang KK, Tortella FC, Hayes RL: Accumulation of calpain and caspase-3 proteolytic fragments of brain-derived alphall-spectrin in cerebral spinal fluid after middle cerebral artery occlusion in rats. J Cereb Blood Flow Metab 2004, 24:98-106.

51. Lewis SB, Velat GJ, Miralia L, Papa L, Aikman JM, Wolper RA, Firment CS, Liu MC, Pineda JA, Wang KK, Hayes RL: Alpha-II spectrin breakdown products in aneurysmal subarachnoid hemorrhage: a novel biomarker of proteolytic injury. J Neurosurg 2007, 107:792-796.

52. Donato R: S-100 proteins. Cell Calcium 1986, 7:123-145.

53. Rustandi RR, Drohat AC, Baldisseri DM, Wilder PT, Weber DJ: The $\mathrm{Ca}(2+)$-dependent interaction of $\mathrm{S} 100 \mathrm{~B}$ (beta beta) with a peptide derived from p53. Biochemistry 1998, 37:1951-1960.

54. Moritz S, Warnat J, Bele S, Graf BM, Woertgen C: The prognostic value of NSE and S100B from serum and cerebrospinal fluid in patients with spontaneous subarachnoid hemorrhage. J Neurosurg Anesthesiol 2010, 22:21-31.

55. Siman R, Giovannone N, Toraskar N, Frangos S, Stein SC, Levine JM, Kumar MA: Evidence that a panel of neurodegeneration biomarkers predicts vasospasm, infarction, and outcome in aneurysmal subarachnoid hemorrhage. PLoS One 2011, 6:e28938.

56. Goyal A, Failla MD, Niyonkuru C, Amin K, Fabio A, Berger RP, Wagner AK: $\mathrm{S} 100 \mathrm{~b}$ as a prognostic biomarker in outcome prediction for patients with severe traumatic brain injury. J Neurotrauma 2013, 30:946-957.

57. Pelinka LE, Kroepfl A, Leixnering M, Buchinger W, Raabe A, Redl H: GFAP versus $\mathrm{S} 100 \mathrm{~B}$ in serum after traumatic brain injury: relationship to brain damage and outcome. J Neurotrauma 2004, 21:1553-1561.

58. Vos PE, Lamers KJ, Hendriks JC, van Haaren M, Beems T, Zimmerman C, van Geel W, de Reus H, Biert J, Verbeek MM: Glial and neuronal proteins in serum predict outcome after severe traumatic brain injury. Neurology 2004, 62:1303-1310.

59. Guzel A, Er U, Tatli M, Aluclu U, Ozkan U, Duzenli Y, Satici O, Guzel E, Kemaloglu S, Ceviz A, Kaplan A: Serum neuron-specific enolase as a predictor of short-term outcome and its correlation with Glasgow Coma Scale in traumatic brain injury. Neurosurg Rev 2008, 31:439-444. discussion 444-445.

60. Papa L, Akinyi L, Liu MC, Pineda JA, Tepas JJ 3rd, Oli MW, Zheng W, Robinson G, Robicsek SA, Gabrielli A, Heaton SC, Hannay HJ, Demery JA, Brophy GM, Layon J, Robertson CS, Hayes RL, Wang KK: Ubiquitin C-terminal hydrolase is a novel biomarker in humans for severe traumatic brain injury. Crit Care Med 2010, 38:138-144.

61. Brophy GM, Mondello S, Papa L, Robicsek SA, Gabrielli A, Tepas J 3rd, Buki A, Robertson C, Tortella FC, Hayes RL, Wang KK: Biokinetic analysis of ubiquitin C-terminal hydrolase-L1 (UCH-L1) in severe traumatic brain injury patient biofluids. J Neurotrauma 2011, 28:861-870.

62. Mondello S, Akinyi L, Buki A, Robicsek S, Gabrielli A, Tepas J, Papa L, Brophy GM, Tortella F, Hayes RL, Wang KK: Clinical utility of serum levels of ubiquitin C-terminal hydrolase as a biomarker for severe traumatic brain injury. Neurosurgery 2012, 70:666-675.

63. Thomas DG, Palfreyman JW, Ratcliffe JG: Serum-myelin-basic-protein assay in diagnosis and prognosis of patients with head injury. Lancet 1978, 1:113-115.

64. Yamazaki Y, Yada K, Morii S, Kitahara T, Ohwada T: Diagnostic significance of serum neuron-specific enolase and myelin basic protein assay in patients with acute head injury. Surg Neurol 1995, 43:267-270. discussion 270-271.

65. Liliang $\mathrm{PC}$, Liang $\mathrm{CL}$, Weng HC, Lu K, Wang KW, Chen HJ, Chuang JH: Tau proteins in serum predict outcome after severe traumatic brain injury. J Surg Res 2010, 160:302-307.

66. Pineda JA, Lewis SB, Valadka AB, Papa L, Hannay HJ, Heaton SC, Demery JA, Liu MC, Aikman JM, Akle V, Brophy GM, Tepas JJ, Wang KK, Robertson CS, Hayes RL: Clinical significance of alphall-spectrin breakdown products in cerebrospinal fluid after severe traumatic brain injury. J Neurotrauma 2007, 24:354-366.

67. Mondello S, Robicsek SA, Gabrielli A, Brophy GM, Papa L, Tepas J, Robertson C, Buki A, Scharf D, Jixiang M, Akinyi L, Muller U, Wang KK, Hayes RL: alphall-spectrin breakdown products (SBDPs): diagnosis and outcome in severe traumatic brain injury patients. J Neurotrauma 2010, 27:1203-1213.

68. Ost M, Nylen K, Csajbok L, Ohrfelt AO, Tullberg M, Wikkelso C, Nellgard P, Rosengren L, Blennow K, Nellgard B: Initial CSF total tau correlates with 1 -year outcome in patients with traumatic brain injury. Neurology 2006, 67:1600-1604

69. Zetterberg H, Smith DH, Blennow K: Biomarkers of mild traumatic brain injury in cerebrospinal fluid and blood. Nat Rev Neurol 2013, 9:201-210

70. Ciccarelli R, Di lorio P, Bruno V, Battaglia G, D'Alimonte I, D'Onofrio M, Nicoletti F, Caciagli F: Activation of A(1) adenosine or mGlu3 metabotropic glutamate receptors enhances the release of nerve growth factor and S-100beta protein from cultured astrocytes. Glia 1999, 27:275-281.

71. Whitaker-Azmitia PM, Murphy R, Azmitia EC: Stimulation of astroglial 5-HT1A receptors releases the serotonergic growth factor, protein S-100, and alters astroglial morphology. Brain Res 1990, 528:155-158.

72. Suzuki F, Kato K, Kato T, Ogasawara N: S-100 protein in clonal astroglioma cells is released by adrenocorticotropic hormone and corticotropin-like intermediate-lobe peptide. J Neurochem 1987, 49:1557-1563.

73. Elting JW, de Jager AE, Teelken AW, Schaaf MJ, Maurits NM, van der Naalt J, Sibinga CT, Sulter GA, De Keyser J: Comparison of serum S-100 protein levels following stroke and traumatic brain injury. J Neurol Sci 2000, 181:104-110.

74. Muller K, Townend W, Biasca N, Unden J, Waterloo K, Romner B, Ingebrigtsen T: S100B serum level predicts computed tomography findings after minor head injury. J Trauma 2007, 62:1452-1456.

75. Zongo D, Ribereau-Gayon R, Masson F, Laborey M, Contrand B, Salmi LR, Montaudon D, Beaudeux JL, Meurin A, Dousset V, Loiseau H, Lagarde E: S100-B protein as a screening tool for the early assessment of minor head injury. Ann Emerg Med 2012, 59:209-218.

76. Rothoerl RD, Woertgen C: High serum S100B levels for trauma patients without head injuries. Neurosurgery 2001, 49:1490-1491. author reply 1492-1493.

77. Marangos PJ, Schmechel DE: Neuron specific enolase, a clinically useful marker for neurons and neuroendocrine cells. Annu Rev Neurosci 1987, 10:269-295

78. Ross SA, Cunningham RT, Johnston CF, Rowlands BJ: Neuron-specific enolase as an aid to outcome prediction in head injury. Br J Neurosurg 1996, 10:471-476.

79. Pelinka LE, Hertz H, Mauritz W, Harada N, Jafarmadar M, Albrecht M, Redl H, Bahrami S: Nonspecific increase of systemic neuron-specific enolase after trauma: clinical and experimental findings. Shock 2005, 24:119-123.

80. Jackson P, Thompson RJ: The demonstration of new human brain-specific proteins by high-resolution two-dimensional polyacrylamide gel electrophoresis. J Neurol Sci 1981, 49:429-438.

81. Tongaonkar P, Chen L, Lambertson D, Ko B, Madura K: Evidence for an interaction between ubiquitin-conjugating enzymes and the $26 \mathrm{~S}$ proteasome. Mol Cell Biol 2000, 20:4691-4698.

82. Papa L, Lewis LM, Silvestri S, Falk JL, Giordano P, Brophy GM, Demery JA, Liu MC, Mo J, Akinyi L, Mondello S, Schmid K, Robertson CS, Tortella FC, Hayes RL, Wang KK: Serum levels of ubiquitin C-terminal hydrolase distinguish mild traumatic brain injury from trauma controls and are elevated in mild and moderate traumatic brain injury patients with intracranial lesions and neurosurgical intervention. J Trauma Acute Care Surg 2012, 72:335-1344.

83. Missler U, Wiesmann M, Wittmann G, Magerkurth O, Hagenstrom $H$ : Measurement of glial fibrillary acidic protein in human blood: analytical method and preliminary clinical results. Clin Chem 1999, 45:138-141.

84. Lumpkins KM, Bochicchio GV, Keledjian K, Simard JM, McCunn M, Scalea T: Glial fibrillary acidic protein is highly correlated with brain injury. J Trauma 2008, 65:778-782. discussion 782-784.

85. Pelinka LE, Kroepfl A, Schmidhammer R, Krenn M, Buchinger W, Redl H, Raabe A: Glial fibrillary acidic protein in serum after traumatic brain injury and multiple trauma. J Trauma 2004, 57:1006-1012.

86. Papa L, Lewis LM, Falk JL, Zhang Z, Silvestri S, Giordano P, Brophy GM, Demery JA, Dixit NK, Ferguson I, Liu MC, Mo J, Akinyi L, Schmid K, Mondello S, Robertson CS, Tortella FC, Hayes RL, Wang KK: Elevated levels of serum glial fibrillary acidic protein breakdown products in mild and moderate traumatic brain injury are associated with intracranial lesions and neurosurgical intervention. Ann Emerg Med 2012, 59:471-483 
87. Okonkwo DO, Yue JK, Puccio AM, Panczykowski DM, Inoue T, McMahon PJ, Sorani MD, Yuh EL, Lingsma HF, Maas Al, Valadka AB, Manley GT, Transforming, Research Clinical Knowledge In Traumatic Brain Injury Investigators, Casey SS, Cheong M, Cooper SR, Dams-O'Connor K, Gordon WA, Hricik AJ, Hochberger K, Menon DK, Mukherjee P, Sinha TK, Schnyer DM, Vassar MJ: GFAP-BDP as an acute diagnostic marker in traumatic brain injury: results from the prospective transforming research and clinical knowledge in traumatic brain injury study. J Neurotrauma 2013, 30:1490-1497

88. Honda M, Tsuruta R, Kaneko T, Kasaoka S, Yagi T, Todani M, Fujita M, Izumi T, Maekawa T: Serum glial fibrillary acidic protein is a highly specific biomarker for traumatic brain injury in humans compared with S-100B and neuron-specific enolase. J Trauma 2010, 69:104-109.

89. Jauch EC, Lindsell C, Broderick J, Fagan SC, Tilley BC, Levine SR: Association of serial biochemical markers with acute ischemic stroke: the National Institute of Neurological Disorders and Stroke recombinant tissue plasminogen activator Stroke Study. Stroke 2006, 37:2508-2513.

90. Foerch C, Singer OC, Neumann-Haefelin T, Du Mesnil De Rochemont R, Steinmetz $\mathrm{H}$, Sitzer M: Evaluation of serum S100B as a surrogate marker for long-term outcome and infarct volume in acute middle cerebral artery infarction. Arch Neurol 2005, 62:1130-1134

91. Dassan P, Keir G, Brown MM: Criteria for a clinically informative serum biomarker in acute ischaemic stroke: a review of S100B. Cerebrovasc Dis 2009, 27:295-302.

92. Jonsson $H$, Johnsson P, Birch-lensen M, Alling C, Westaby S, Blomquist S: S100B as a predictor of size and outcome of stroke after cardiac surgery. Ann Thorac Surg 2001, 71:1433-1437.

93. Ahmad O, Wardlaw J, Whiteley WN: Correlation of levels of neuronal and glial markers with radiological measures of infarct volume in ischaemic stroke: a systematic review. Cerebrovasc Dis 2012, 33:47-54.

94. Hill MD, Jackowski G, Bayer N, Lawrence M, Jaeschke R: Biochemical markers in acute ischemic stroke. CMAJ 2000, 162:1139-1140.

95. Foerch C, Otto B, Singer OC, Neumann-Haefelin T, Yan B, Berkefeld J, Steinmetz $H$, Sitzer M: Serum S100B predicts a malignant course of infarction in patients with acute middle cerebral artery occlusion. Stroke 2004, 35:2160-2164.

96. Foerch C, Wunderlich MT, Dvorak F, Humpich M, Kahles T, Goertler M, Alvarez-Sabin J, Wallesch CW, Molina CA, Steinmetz H, Sitzer M, Montaner J: Elevated serum S100B levels indicate a higher risk of hemorrhagic transformation after thrombolytic therapy in acute stroke. Stroke 2007 38:2491-2495

97. Kazmierski R, Michalak S, Wencel-Warot A, Nowinski WL: Serum tight-junction proteins predict hemorrhagic transformation in ischemic stroke patients. Neurology 2012, 79:1677-1685.

98. Saenger AK, Christenson RH: Stroke biomarkers: progress and challenges for diagnosis, prognosis, differentiation, and treatment. Clin Chem 2010, 56:21-33.

99. Yoo JH, Lee SC: Elevated levels of plasma homocyst(e)ine and asymmetric dimethylarginine in elderly patients with stroke. Atherosclerosis 2001, 158:425-430.

100. Leong T, Zylberstein D, Graham I, Lissner L, Ward D, Fogarty J, Bengtsson C, Bjorkelund C, Thelle D: Asymmetric dimethylarginine independently predicts fatal and nonfatal myocardial infarction and stroke in women: 24-year follow-up of the population study of women in Gothenburg. Arterioscler Thromb Vasc Biol 2008, 28:961-967.

101. Pikula A, Boger RH, Beiser AS, Maas R, DeCarli C, Schwedhelm E, Himali JJ, Schulze F, Au R, Kelly-Hayes M, Kase CS, Vasan RS, Wolf PA, Seshadri S: Association of plasma ADMA levels with MRI markers of vascular brain injury: Framingham offspring study. Stroke 2009, 40:2959-2964.

102. Clark AW, Krekoski CA, Bou SS, Chapman KR, Edwards DR: Increased gelatinase A (MMP-2) and gelatinase B (MMP-9) activities in human brain after focal ischemia. Neurosci Lett 1997, 238:53-56.

103. Alvarez-Sabin J, Delgado P, Abilleira S, Molina CA, Arenillas J, Ribo M, Santamarina E, Quintana M, Monasterio J, Montaner J: Temporal profile of matrix metalloproteinases and their inhibitors after spontaneous intracerebral hemorrhage: relationship to clinical and radiological outcome. Stroke 2004, 35:1316-1322.

104. Montaner J, Alvarez-Sabin J, Molina C, Angles A, Abilleira S, Arenillas J, Gonzalez MA, Monasterio J: Matrix metalloproteinase expression after human cardioembolic stroke: temporal profile and relation to neurological impairment. Stroke 2001, 32:1759-1766.
105. Montaner J, Alvarez-Sabin J, Molina CA, Angles A, Abilleira S, Arenillas J, Monasterio J: Matrix metalloproteinase expression is related to hemorrhagic transformation after cardioembolic stroke. Stroke 2001, 32:2762-2767

106. Montaner J, Molina CA, Monasterio J, Abilleira S, Arenillas JF, Ribo M, Quintana M, Alvarez-Sabin J: Matrix metalloproteinase-9 pretreatment level predicts intracranial hemorrhagic complications after thrombolysis in human stroke. Circulation 2003, 107:598-603.

107. Rosell A, Alvarez-Sabin J, Arenillas JF, Rovira A, Delgado P, Fernandez-Cadenas I, Penalba A, Molina CA, Montaner J: A matrix metalloproteinase protein array reveals a strong relation between MMP-9 and MMP-13 with diffusion-weighted image lesion increase in human stroke. Stroke 2005, 36:1415-1420.

108. Gappoeva MU, Izykenova GA, Granstrem OK, Dambinova SA: Expression of NMDA neuroreceptors in experimental ischemia. Biochemistry (Mosc) 2003, 68:696-702.

109. Dambinova SA, Bettermann K, Glynn T, Tews M, Olson D, Weissman JD, Sowell RL: Diagnostic potential of the NMDA receptor peptide assay for acute ischemic stroke. PLoS One 2012, 7:e42362.

110. Dambinova SA, Khounteev GA, Izykenova GA, Zavolokov IG, Ilyukhina AY, Skoromets AA: Blood test detecting autoantibodies to N-methyl-D-aspartate neuroreceptors for evaluation of patients with transient ischemic attack and stroke. Clin Chem 2003, 49:1752-1762

111. Bokesch PM, Izykenova GA, Justice JB, Easley KA, Dambinova SA: NMDA receptor antibodies predict adverse neurological outcome after cardiac surgery in high-risk patients. Stroke 2006, 37:1432-1436.

112. Herrmann M, Vos P, Wunderlich MT, de Bruijn CH, Lamers KJ: Release of glial tissue-specific proteins after acute stroke: a comparative analysis of serum concentrations of protein S-100B and glial fibrillary acidic protein. Stroke 2000, 31:2670-2677.

113. Foerch C, Curdt I, Yan B, Dvorak F, Hermans M, Berkefeld J, Raabe A, Neumann-Haefelin T, Steinmetz H, Sitzer M: Serum glial fibrillary acidic protein as a biomarker for intracerebral haemorrhage in patients with acute stroke. J Neurol Neurosurg Psychiatry 2006, 77:181-184.

114. Dvorak F, Haberer I, Sitzer M, Foerch C: Characterisation of the diagnostic window of serum glial fibrillary acidic protein for the differentiation of intracerebral haemorrhage and ischaemic stroke. Cerebrovasc Dis 2009, 27:37-41.

115. Unden J, Strandberg K, Malm J, Campbell E, Rosengren L, Stenflo J, Norrving B, Romner B, Lindgren A, Andsberg G: Explorative investigation of biomarkers of brain damage and coagulation system activation in clinical stroke differentiation. J Neurol 2009, 256:72-77.

116. Ernst A, Suhr J, Kohrle J, Bergmann A: Detection of stable N-terminal protachykinin A immunoreactivity in human plasma and cerebrospinal fluid. Peptides 2008, 29:1201-1206.

117. Doehner W, von Haehling S, Suhr J, Ebner N, Schuster A, Nagel E, Melms A, Wurster T, Stellos K, Gawaz M, Bigalke B: Elevated plasma levels of neuropeptide proenkephalin a predict mortality and functional outcome in ischemic stroke. J Am Coll Cardiol 2012, 60:346-354.

118. Reynolds MA, Kirchick HJ, Dahlen JR, Anderberg JM, McPherson PH, Nakamura KK, Laskowitz DT, Valkirs GE, Buechler KF: Early biomarkers of stroke. Clin Chem 2003, 49:1733-1739.

119. Laskowitz DT, Blessing R, Floyd J, White WD, Lynch JR: Panel of biomarkers predicts stroke. Ann N Y Acad Sci 2005, 1053:30.

120. Laskowitz DT, Kasner SE, Saver J, Remmel KS, Jauch EC: Clinical usefulness of a biomarker-based diagnostic test for acute stroke: the Biomarker Rapid Assessment in Ischemic Injury (BRAIN) study. Stroke 2009, 40:77-85.

121. Montaner J, Mendioroz M, Ribo M, Delgado P, Quintana M, Penalba A, Chacon P, Molina C, Fernandez-Cadenas I, Rosell A, Alvarez-Sabin J: A panel of biomarkers including caspase- 3 and D-dimer may differentiate acute stroke from stroke-mimicking conditions in the emergency department. J Intern Med 2011, 270:166-174.

122. Doehner W: Diagnostic biomarkers in cardiovascular disease: the proteomics approach. Eur Heart J 2012, 33:2249-2251.

$10.1186 / \mathrm{cc} 13841$

Cite this article as: Mrozek et al.: Biomarkers and acute brain injuries: interest and limits. Critical Care 2014, 18:220 